\title{
COMMENTARY
}

\section{SOMATOSTATIN ANALOGS: CLINICAL APPLICATION IN RELATION TO HUMAN SOMATOSTATIN RECEPTOR SUBTYPES}

\author{
LEO J. HOFLAND, * HELEEN A. VISSER-WISSELAAR and \\ STEVEN W. J. LAMBERTS \\ Department of Internal Medicine III, Erasmus University Rotterdam, 3015 GD Rotterdam, The \\ Netherlands
}

Key words: somatostatin analog; receptor subtype; tumor; binding; function; internalization

\section{Somatostatin and somatostatin analogs}

SRIF $\uparrow$ was described originally by Krulich et al. [1] as a factor present in hypothalamic extracts capable of inhibiting $\mathrm{GH}$ release by cultured rat anterior pituitary cells. Brazeau etal. [2] characterized this factor as a cyclic peptide (SS14) consisting of 14 amino acids. Several years later, a second bioactive form, an $\mathrm{NH}_{2}$-terminally extended somatostatin molecule, consisting of 28 amino acids (SS28), was isolated and characterized [3]. In mammals, both SS14 and SS28 originate from a $10.3 \mathrm{kDa}$ prohormone called preprosomatostatin [4].

Somatostatin has an inhibitory action on a variety of physiological functions in different organ systems, including the hypothalamus, the anterior pituitary gland, the gastrointestinal tract, and the endocrine and exocrine pancreas [5]. In the brain, somatostatin may have a role in neurotransmission, both stimulatory and inhibitory $[6,7]$. On the basis of its widespread inhibitory actions, somatostatin may play a role in the treatment of human disease due to hyperfunction of the above organ systems. However, the clinical use of somatostatin was hampered because the native peptide had several disadvantages $[8,9]$. In particular, the need for continuous i.v. infusion due to its very short halflife in the circulation ( $<3 \mathrm{~min}$ ), its diversity of action (i.e. its potent inhibitory action on normal insulin secretion), and, finally, the rebound hypersecretion of hormones by normal tissues after SS14 infusion are major disadvantages $[10,11]$. A logical step, therefore, was the development of structural analogs of somatostatin, not having the disadvantages of SS14 as described above. This research has led to

* Corresponding author: Dr. L. J. Hofland, Internal Medicine III, Academic Hospital Dijkzigt, 40 Dr. Molewaterplein, 3015 GD Rotterdam, The Netherlands. Tel. 31-10-4635967; FAX 31-10-4635430.

$\uparrow$ Abbreviations: $b F G F$, basic fibroblast growth factor; cAMP, cyclic adenosine monophosphate; $\mathrm{E}_{2}, 17 \beta$-estradiol; FBS, fetal bovine serum; GEP, gastroenteropancreatic GH, growth homione; RT-PCR, reverse transcriptase polymerase chain reaction; SRIF, somatotropin release inhibiting factor; SS14, somatostatin-14; SS28, somatostatin-28; SS-R, somatostatin receptor (protein); and SSTR, somatostatin receptor (gene). the synthesis of a great number of somatostatin analogs; thus far, three of them, octreotide (SMS 201-995, Sandostatin), BIM-23014 (Lanreotide) and RC-160 (Octastatin, Vapreotide), are in clinical studies and/or use. Figure 1 shows the amino acid sequence of each of these analogs, in comparison with that of the native peptide. Until now, octrcotide was the most widely used somatostatin analog for the treatment of human tumors [12].

Bauer et al. [13] originally developed via step-bystep modification of the conformationally stabilized central part of the SS14 molecule a series of highly potent octapeptide analogs, of which octreotide was the most active. This analog contains the sequence of residues 7-10 of SS14, Phe-Trp-I ys-Thr, essential for receptor binding, in which D-Trp was substituted for Trp (Fig. 1). Octreotide can be given subcutaneously, has a half-life of approximately $2 \mathrm{hr}$ and turned out to be 45 times more active than SS14 in inhibiting $\mathrm{GH}$ release in monkeys, 11 times more effective in inhibiting glucagon release, and most important, only 1.3 times more potent in inhibiting insulin release [13]. Thereafter, several analogs, related to octreotide, were synthesized and tested for their biological activity by Schally and co-workers $[14,15]$. They found that substitution of Phe and Thr by Tyr and Val, respectively, at positions 3 and 6 resulted in a much higher potency for inhibition of GH secretion, but lower activity for inhibition of insulin and glucagon release in vivo in rats. They also suggested that replacing Thr at position 8 with Trp may result in increased receptor affinity. This suggests that analogs containing the $\mathrm{Tyr}^{3} / \mathrm{Val}^{6}$ substitution may be more specific for $\mathrm{GH}$ inhibition, and that there may be selectivity in the actions of octapeptide analogs. Both RC-160 and BIM-23014 are $\mathrm{Tyr}^{3} / \mathrm{Val}^{6}$-containing somatostatin analogs; $\mathrm{RC}$ 160 also has Trp at position 8, and BIM-23014 $\beta \mathrm{Nal}$ at position 1. In addition to RC-160, BIM23104 was chosen with the intention of finding an analog with little effect on insulin and glucagon secretion but with a more profound effect on $\mathrm{GH}$ secretion $[16,17]$. The above data also suggest the existence of multiple SS-R subtypes having selective affinities for structural analogs of somatostatin, and with a selective expression in different organ systems. 
somatostatin- $14 \quad$ H-Ala-Gly-Cys-Lys-Asn-Phe-Phe-Trp-Lys-Thr-Phe-Trr-Ser
octreotide
BIM-23014 H-DBNal-Cys-Tyr-DTrp-Lys-Val-Cys-Tro-NH2
RC- 160

Fig. 1. Structures of somatostatin-14, octreotide, BIM-23014 and RC-160.

This concept was further substantiated by the recent cloning of at least five different human SSTR subtypes (see below). As has been mentioned above, along with octreotide, RC-160 and BIM-23014, many other somatostatin analogs have been synthesized thus far. In this review, we will summarize the relevant literature data on binding of somatostatin analogs to human SSTR subtypes, as well as SSTR subtype expression in normal and tumorous tissues, and we will discuss the clinical role of somatostatin analogs in relation to SSTR subtypes.

\section{Somatostatin receptors in normal and tumorous tissues}

Along with the widespread biological actions of somatostatin, high-affinity SS-Rs have been identified in all somatostatin target tissues. High-affinity somatostatin binding sites have been demonstrated in the anterior pituitary gland, the endocrine and exocrine pancreas, the gastrointestinal tract and the central nervous system. It has also become evident that many human neuroendocrine tumors, often originating from somatostatin target tissues, carry receptors for somatostatin $[18,19]$. Most of these human tumors containing a high density of SSRs have classical amine precursor uptake and decarboxylation (APUD) characteristics, and include pituitary adenomas, islet cell tumors, pheochromocytomas, paragangliomas, small cell lung cancers, medullary thyroid carcinomas and carcinoids [12]. In addition, other subgroups of tumors arising from dispersed neuroendocrine cells in organs like the breast, brain, colon and lung have been shown to carry SS-Rs both by in vitro studies using homogenate binding and receptor autoradiography, as well as by in vivo localization of primary tumors and their metastases by scintigraphy with the radiolabeled somatostatin analog octreotide. Krenning et al. [20] recently reviewed the results of the Rotterdam study of SSTR scintigraphy using [ ${ }^{123}$ ITyr $^{3}$ ]octreotide and [ ${ }^{111}$ In-DTPA-D-Phe ${ }^{1}$ ]octreotide in 1000 patients.

\section{Somatostatin receptor subtypes}

Ligand-binding studies. By using the techniques of homogenate ligand binding and in vitro receptor autoradiography, evidence has been obtained for the existence of SS-R subtypes on the basis of a differential binding of native somatostatin (SS14 and SS28) and of several structural analogs of somatostatin. Reubi et al. $[21,22]$ and Tran et al. [23] showed that the somatostatin analog octeotide only partially displaced, although with high affinity, $\left[{ }^{125}\left[-\mathrm{Tyr}^{11}\right] \mathrm{SS} 14\right.$ binding to rat cortical membranes. On the basis of their experiments, they suggested the existence of at least two somatostatin binding sites in the rat brain: an SS-R with high affinity for octreotide and an SS-R with low affinity for this somatostatin analog. Autoradiographic studies have also demonstrated the existence of SS-R subtypes in rat brain on the basis of distinct regional distribution patterns using different somatostatin analogs [24, 25]. Also, functional studies point to the presence of SS$\mathbf{R}$ subtypes in the brain. Inhibition of forskolinstimulated adenylyl cyclase activity by somatostatin was observed in membrane preparations from the rat hippocampus and striatum but not from the substantia nigra. Moreover, octreotide solely inhibited adenylyl cyclase activity in the preparations, while SS14 also stimulated adenylyl cyclase activity at micromolar concentrations [26].

By using SS-R autoradiography, a differential binding pattern of SS14 or SS28 on the one hand and of octreotide on the other hand has also been observed in subgroups of human tumors. In a small subgroup of insulinomas, carcinoids, medullary thyroid carcinomas, ovarian cancers and $\mathrm{GH}$ secreting pituitary adenomas, no binding of $\left[{ }^{125} \mathrm{I}\right.$ $\mathrm{Tyr}^{3}$ ]octreotide could be demonstrated by autoradiography, while binding sites for SS14 and SS28 were present $[18,19]$. In general, however, a good correlation exists between the absence or presence of binding sites for somatostatin and the absence or presence of a clinical beneficial effect of octreotide in patients treated with the drug [12]. The above data suggest the presence of multiple SS-R subtypes in human tumors showing peptide specificities. Schally's group also provided evidence for SS-R subtypes in human cancers. They showed in membrane preparations of human breast and 
ovarian cancers and of several human pancreatic adenocarcinomas that RC-160 has a considerable higher affinity for SS14-binding sites than does octreotide [27]. These latter data also suggest that among different octapeptide analogs of octreotide, there may be, in certain cases, a differential binding to SS-R subtypes.

Cross-linking studies. Cross-linking is a biochemical method to study molecular forms of SSRs. With this technique, radiolabeled ligands are covalently coupled to receptor proteins. The radiolabeled ligand-receptor complex can be analyzed further by chromatography or by polyacrylamide gel electrophoresis followed by autoradiography. The SS-Rs detected by this technique vary considerably in molecular mass. A recent overview by Rens-Domiano and Reisine [28] shows that the molecular mass of SS-R ranges from 27 to $228 \mathrm{kDa}$. It is at present unclear what causes this heterogeneity in molecular mass. The existence of more than one receptor subtype has already been outlined above. It is also possible that the cross-linking technique itself introduces artifacts, especially when small peptide analogs are used as ligands. It is known that the properties of the cross-linking agents (i.e. spacerarm length and hydrophobicity), as well as the composition and length of the ligand, influence the effectiveness of the reaction. Notwithstanding, size differences were also observed when the same tissue and method were used. Ligand selectivity has been reported by Murthy et al. [29] and Patel et al. [30]. $\mathrm{Tyr}^{3}$-octeotide seems to have specific affinity for a $27-\mathrm{kDa}$ molecular form in AtT20 cells and in rat brain membrane preparations.

The recently cloned five human SSTR genes (see below) all encode proteins with estimated molecular masses of approximately 39 to $46 \mathrm{kDa}$. Posttranslational modifications like sugar chain addition and proteolytic processing are known to influence the molecular weight of proteins considerably, thereby affecting the mobility of proteins in SDSPAGE. Studies by Eppler et al. [31] have demonstrated that approximately half of the apparent molecular weight of the SS-R present in $\mathrm{GH}_{4} \mathrm{C}_{1}$ cells is due to covalently bound carbohydrate.

Potential sites for the attachment of $\mathrm{N}$-linked carbohydrate side chains (-Asn-Xaa-Ser/Thr, Xaa being any amino acid except proline) are present in the deduced amino acid sequences of the cloned SSTRs. However, not all potential glycosylation sites are used. There are, for instance, attachment sites for sugar chains located in the signal peptide sequence and in a transmembrane spanning domain. It is unlikely that these sites will be glycosylated in vivo. Sugar chain addition could be of functional significance for the structure of the ligand binding site. Rens-Domiano and Reisine [32] found a reduced affinity for the iodinated somatostatin analog MK678 after desialylation of brain SS-Rs and AtT20 cell SS-Rs. The role of each individual glycosylation site can be established in future studies via site-directed mutagenesis followed by expression of the mutant DNA construct.

Because the different molecular forms of the SS$R$ may represent different SSTR subtypes or processing variants of one SSTR subtype, the production of subtype-specific antibodies seems necessary to further understand and match the data derived from the molecular cloning and the crosslinking studies. Metabolic labeling in combination with immunoprecipitation studies will give a more precise insight into the biosynthesis and posttranslational modifications of SSTRs. A recent report mentions the production of a polyclonal antiserum raised against a synthetic peptide that codes for a specific part of the human SSTR2 sequence [33].

Although the presence of different SS-R proteins has been studied extensively by the method of crosslinking in a variety of normal tissues [28], much less is known with respect to different SS-R proteins in human tumors. In human breast tumors, the somatostatin analog BIM-23014 complexed with three distinct SS-R proteins of 27,42 and $57 \mathrm{kDa}$, while there was a considerable heterogeneity among the tumor specimens in the expression of the different proteins $[34,35]$. A significant positive correlation was found between the absence of sex steroid receptors and the simultaneous presence of the three BIM-23014 binding receptor proteins [34].

Molecular biology. From the above data it is clear that in both normal tissues (i.e. brain) and tumorous tissues (i.e. human insulinomas) at least more than one SS-R subtype is present. This concept was confirmed recently by the cloning of five different human, mouse and rat SSTR subtypes (SSTR1-5). Because this review deals with the clinical use of somatostatin analogs in relation to SSTR subtypes, and differences have been reported in binding characteristics between the same human and rat SSTR subtypes, we will focus on the five human SSTR (hSSTR) subtypes only. The five hSSTR subtypes consisting of $391,369,418,388$ and 363 amino acids, respectively, show an amino acid identity ranging from 42 to $60 \%$ [36]. hSSTR1, hSSTR2, hSSTR3, hSSTR4 and hSSTR5 have been shown to be localized on chromosomes $14 q 13,17 q 24$, $22 q 13.1,20$ and 16, respectively [37-40]. In another study, Yasuda et al. reported localization of the hSSTR5 subtype to chromosome 20p11.2 [41]. However, in this study an hSSTR5 genomic clone isolated from a human genomic library by hybridization with a polymerase chain reactiongenerated fragment of the rat SSTR4 gene [42] was used and may therefore be considered as an hSSTR 4 clone.

Table 1 summarizes some characteristics of the five hSSTR subtypes. Certainly more information will become available in the near future. Initially it seemed that the different hSSTR subtypes were differentially coupled to adenylate cyclase [38, 4346]. However, it is now clear that all five SSTR subtypes are functionally coupled to adenylate cyclase via a pertussis toxin-sensitive G-proteincoupled mechanism. Kaupmann et al. [47] recently demonstrated that somatostatin (analogs) inhibited forskolin-induced cAMP formation in HEK 293 human embryonal kidney cells stably expressing the hSSTR1-4 subtypes. The inhibition of cAMP formation was pertussis toxin sensitive, indicating the coupling of hSSTR1-4 to pertussis toxin-sensitive G-proteins. In addition, Patel et al. [48] established 


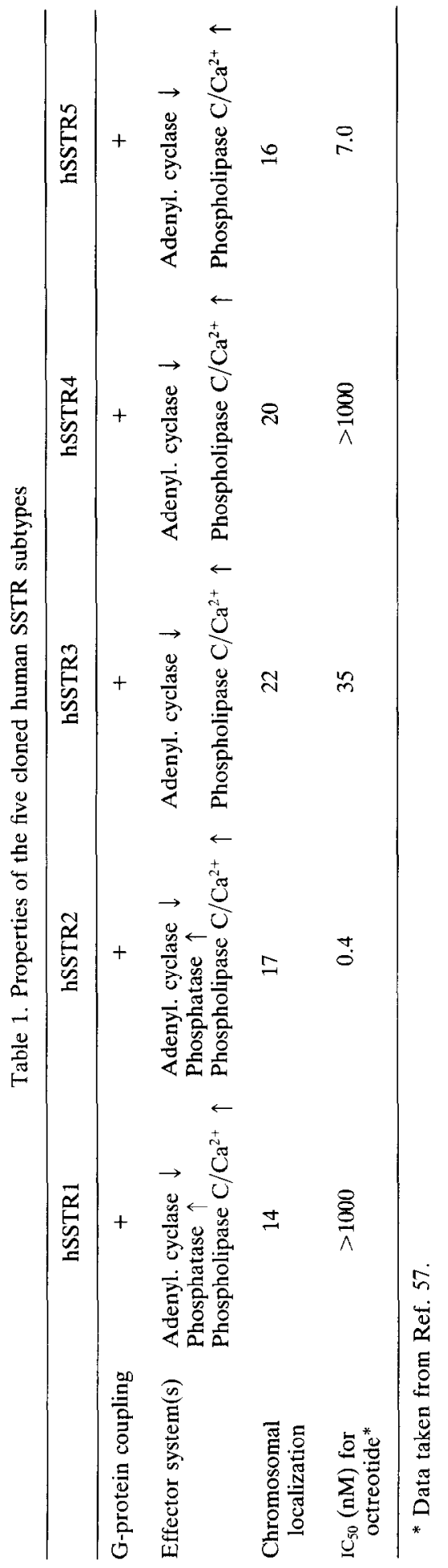

stably transfected CHO-K1 cells expressing the human genes for SSTR1-5. These five expressed hSSTRs all bound SS14 and SS28 with high affinity, and both SS14 and SS28 inhibited forskolinstimulated cAMP accumulation with $\mathrm{ED}_{50}$ values comparable to their binding affinities for the individual hSSTR subtypes. Pretreatment of the cells with pertussis toxin resulted in a marked reduction $(30-70 \%)$ of ${ }^{125}$ I]LTT SS28 binding to the five receptors, again suggesting that all five hSSTR subtypes are coupled to adenylyl cyclase via pertussis toxin-sensitive G-proteins. Recently, Tomura et al. [49] have shown that activation of the human SSTR15 subtypes may also be linked to phospholipase $\mathrm{C}$ stimulation and $\mathrm{Ca}^{2+}$ mobilization. The order of potency for somatostatin-induced inositol phosphate production was hSSTR5 $>$ hSSTR2 $>$ hSSTR3 $>$ hSSTR4 $>$ hSSTR1 [50]. In addition, they found that inhibition of cAMP formation could be reversed by pertussis toxin, whereas SS-induced activation of phospholipase $\mathrm{C}$ and $\mathrm{Ca}^{2+}$ mobilization was blocked only partially by pertussis toxin in hSSTR2, hSSTR3 and hSSTR 5 transfected COS-7 cells, indicating that both pertussis toxin-sensitive and -insensitive GTPbinding proteins may be linked to one hSSTR subtype. These investigators suggested that, similar to receptors for thyrotropin, luteinizing hormone, tachykinin and calcitonin, one human SSTR subtype may also be linked to more than one effector system $[49,50]$. This is also evident from the observations of Buscail et al. [51], who showed that both octreotide and RC- 160 caused stimulation of tyrosine phosphatase activity in COS-7 cells transiently expressing hSSTR2, while RC-160 but not octreotide also stimulated phosphatase activity in cells transfected with the hSSTR1 subtype. In the same study, it was shown that in NIH 3T3 cells stably expressing hSSTR1 or 2, both RC-160 and octreotide inhibited bFGF- and bFGF- or FBS-stimulated cell proliferation, respectively, with RC-160 being slightly more efficacious than octreotide [51].

Despite the fact that there is a relatively high homology in amino acid identity, a common link to adenylyl cyclase activity, a common G-protein coupling, and high-affinity binding of SS14 and SS28 to all hSSTR subtypes $[47,48]$, several differences have been observed thus far in the binding affinities of structural analogs of somatostatin to the hSSTR15 subtypes. As has been mentioned before, all five hSSTR subtypes bind SS14 and SS28 with high affinity. Octrcotide binds with high affinity to the hSSTR2 subtype and binds with moderate affinity to the hSSTR3 [44] and hSSTR5 subtypes ([36, 38]; Table 1). However, this somatostatin analog shows no binding to the hSSTR $1[45,52]$ and hSSTR4 $[36,53]$ subtypes. In several studies (although less extensively studied than octreotide), binding of RC160 and BIM-23014 to human SSTR subtypes was investigated. RC- 160 has a very low affinity, although higher than that of octreotide, for the hSSTR4 subtype $[36,53]$, while it shows a higher affinity (approximately 2- to 8-fold) in comparison with octreotide for the hSSTR5 subtype [36, 38]. This higher affinity of RC-160 as compared with octreotide has also been demonstrated for the hSSTR1 and 2 subtypes (2- and 3-fold respectively; [51]). In the 
Table 2. Time-dependent binding and internalization of $\left[{ }^{125} \mathrm{I}-\mathrm{Tyr}^{3}\right]$ octreotide by cultured human carcinoid cells

\begin{tabular}{|c|c|c|c|}
\hline & \multirow{2}{*}{$\begin{array}{c}\text { Incubation } \\
\text { time }(\mathrm{hr})\end{array}$} & \multicolumn{2}{|c|}{$\left[{ }^{125} \mathrm{I}-\mathrm{Tyr}^{3}\right]$ Octreotide (\% dose) } \\
\hline & & Control & Octreotide $(1 \mu \mathrm{M})$ \\
\hline \multirow[t]{2}{*}{ Membrane-bound } & 1 & $0.78 \pm 0.01$ & $0.62 \pm 0.04^{*}$ \\
\hline & 4 & $1.10 \pm 0.02$ & $0.59 \pm 0.01^{*}$ \\
\hline \multirow[t]{2}{*}{ Internalized } & 1 & $0.63 \pm 0.07$ & $0.14 \pm 0.06^{*}$ \\
\hline & 4 & $2.33 \pm 0.06$ & $0.33 \pm 0.03^{*}$ \\
\hline
\end{tabular}

Human carcinoid cells were incubated with approximately $0.1 \mathrm{nM}\left[{ }^{125} \mathrm{I}-\mathrm{Tyr}^{3}\right]$ octreotide in the presence or absence of $1 \mu \mathrm{M}$ unlabeled octreotide to determine specificity of membrane binding and internalization. At the end of the indicated incubation periods, membrane-bound and internalized radioactivity was determined by acid-stripping. Values are means \pm SEM, $N=4$ wells per group.

${ }^{*} \mathrm{P}<0.01$ vs control.

study by Panetta et al. [38], BIM-23014 also displaced ${ }^{125}$ I-LTT-SS28 binding to the hSSTR5 subtype with a 5-fold higher potency than octreotide. The binding characteristic of the somatostatin analog MK-678 to hSSTR5 was similar to that of octreotide [38].

Raynor et al. [52] showed in extensive studies that BIM-23014 and octreotide possess a very low affinity for the hSSTR1 subtype and a relative high affinity ( 1.6 to $5.6 \mathrm{nM}$ ) for the mouse SSTR2 and 3 subtypes. Since octreotide binds to the human SSTR3 subtype with an approximately 6-fold lower affinity, this again emphasizes that care must be taken with the extrapolation of ligand-binding data of mouse and rat SSTR subtypes to the human situation. Interestingly, Raynor et al. [52] also found that some linear analogs of somatostatin selectively bound to SSTR subtypes with subnanomolar affinities, whereas CGP 23966-like compounds (structure: cyclo[AhepLys-Asn-Phe-Phe-Trp-Lys-Thr-Tyr-Thr-Ser]) bound to the hSSTR1 subtype, but not to the mouse SSTR2 subtype [45]. In addition, it was found that CGP23966 bound with high affinity to the hSSTR3 subtype [44]. Therefore, studies directed to the development of somatostatin analogs, other than octapeptide analogs, may result in new classes of somatostatin analogs that might be of therapeutic value in the treatment of human tumors not expressing the hSSTR2 subtype, which has a high affinity for the somatostatin analogs octreotide, BIM-23014 and RC-160. Much of the therapeutic value of new agents will also depend on their pharmacokinetic properties, however. Depending on these properties, such analogs may be of therapeutic value in the treatment of those tumors that show no binding of octreotide, RC-160 and BIM-23014.

Taken together, these data indicate that there may be relative differences (up to 10 -fold) in binding affinities to SSTR1-5 subtypes among the three octapeptide somatostatin analogs available for clinical use now. It is also clear that none of these analogs binds with high affinity to the hSSTR1, hSSTR 3 and hSSTR4 subtypes, whereas all bind hSSTR2 and hSSTR5 with a high and relatively high affinity, respectively.

\section{Somatostatin receptor subtype expression in human tumors}

There is a limited number of studies, thus far, showing the expression of SSTR subtypes in human tumors. Greenman and Melmed [54] showed heterogeneous expression of the hSSTR1 and hSSTR2 subtypes in human pituitary tumors using RNAse protection assays. They found that hSSTR 1 and hSSTR2 were expressed, respectively, in 3 of 7 and 9 of $10 \mathrm{GH}$-secreting pituitary adenomas, 4 of 5 and 0 of 5 prolactinomas, 1 of 9 and 5 of 9 nonfunctioning adenomas, and in 1 of 3 and 0 of 3 ACTH-secreting tumors. They also found that two acromegalic patients who responded to octreotide therapy exclusively expressed the hSSTR2 subtype in their tumors, suggesting that the hSSTR2 subtype mediates the antihormonal action of octreotide in these tumors. In this respect, the observation by Raynor et al. [52] that the potencies of various somatostatin agonists to inhibit growth hormone secretion in vitro were highly correlated with their potencies to inhibit radioligand binding to the mouse SSTR2 receptor, but not to the hSSTR1 or mouse SSTR3 subtype, is of particular interest. In the nonfunctioning pituitary adenomas, the role of the hSSTR2 subtype is less clear, although it has been shown recently that octreotide may also have an inhibitory action on gonadotrophin and/or gonadotrophin-subunit secretion by clinically nonfunctioning pituitary adenomas in vivo and in vitro $[55,56]$. Panetta $e t$ al. ${ }^{*}$ reported the presence of hSSTR2 and hSSTR3, but not hSSTR5 mRNA in a $\mathrm{GH}$-adenoma, a prolactinoma, and one of two chromophobe adenomas. The other chromophobe adenoma did not express the hSSTR2, 3 or 5 subtype. hSSTR1 and hSSTR4 expression was not tested.

The importance of the hSSTR2 subtype in mediating the clinical effects of octreotide is further substantiated by a recent study by Kubota et al. [57]. These investigators showed, by using RT-PCR, the

${ }^{*}$ Panetta R, Kent G, Greenwood $\mathrm{M}$ and Patel YC, Normal pituitary and pituitary tumor cells express multiple somatostatin receptor (SSTR) subtype genes. Program \& Abstracts of the 75th Annual Meeting of the Endocrine Society, Abstr. No. 1441, 1993. 
expression of hSSTR1, hSSTR2, hSSTR3 and hSSTR4 in two cases of glucagonoma and its metastatic lymph node in one case. In addition, a heterogeneous expression of these hSSTR subtypes was found in four insulinomas. Whereas all insulinomas showed expression of hSSTR1 and hSSTR4, hSSTR2 was not detected in one case, and hSSTR3 was absent in two cases. One carcinoid expressed hSSTR1 and hSSTR4 only, while three pheochromocytomas expressed the hSSTR1 and hSSTR2 subtype only. None of the tumor samples showed expression of the hSSTR5 subtype. Most important, these investigators also showed that urinary 5-hydroxyindole acetic acid (5-HIAA) excretion in the patient with a metastatic carcinoid lacking hSSTR2 expression was not lowered by octreotide treatment, while octreotide treatment lowered plasma glucagon levels in the patient with an hSSTR2 positive glucagonoma. This again strongly suggests that the efficacy of octreotide treatment may depend, at least in part, on the expression of hSSTR2 in tumors [57]. It should be noted, however, that amplification by RT-PCR of hSSTR subtype mRNAs from contaminating normal tissues cannot be excluded completely in these studies. Studies using in situ hybridization for the detection of hSSTR subtype mRNAs in tumor slices may help to answer this question. Of special importance in this respect is that Reubi et al. [58] recently demonstrated the presence of somatostatin receptors in veins surrounding different types of human cancer tissue. Using in situ hybridization histochemistry, Reubi et al. [59] studied hSSTR1, hSSTR 2 and hSSTR 3 mRNA expression in 55 human primary tumors. Most abundantly expressed was the hSSTR2 subtype. In all pituitary adenomas, meningiomas, neuroblastomas, breast tumors and small cell lung cancers, and in a majority of GEP tumors and lymphomas, hSSTR 2 mRNA expression was found. hSSTR1 and hSSTR 3 mRNA cxpression was observed less frequently, but most regularly found in GEP tumors, medullary thyroid cancers and ovarian cancers. In general, a good correlation was seen between the presence of hSSTR 2 mRNA and binding of ${ }^{125}\left[-\mathrm{Tyr}^{3}\right]$ octreotide, using receptor autoradiography [59].

An intriguing question remains however: what is the functional role of the other hSSTR subtypes that are also expressed in part of the human tumors? It is clear that the development of new somatostatin analogs with a more selective action to the hSSTR1, 3,4 and 5 subtype is needed to answer this question. In several human and rodent solid transplantable tumors and in tumor cell lines (i.e. lung, breast, colon, pancreas and prostate origin), Eden and Taylor [60] showed expression of the hSSTR2 subtype in all tumors, while there was a differential expression of the hSSTR1 and hSSTR3 subtypes, as determined by RT-PCR. In breast tumor cell lines such as MCF7, MDA MB231, and ZR-75-1, expressing solely the hSSTR2 subtype [60], octreotide and BIM-23014 were shown to inhibit cell proliferation in other studies [61-66]. It is not clear, however, whether octreotide in these cell lines mediates an indirect (via the inhibition of the secretion of autocrine/paracrine growth factors,
hSSTR2-mediated?) or a direct cell growth inhibitory effect.

Functional studies with somatostatin analogs: Relation to somatostatin receptor subtypes

SS-Rs have been shown to be linked to different intracellular effector systems such as adenylyl cyclase, ion channels and phosphatases [30]. It is evident that somatostatin (analogs) may have both antihormonal and antiproliferative effects in a variety of normal and tumorous cell systems [12]. The possible mechanisms of action of the tumor growth inhibitory effects by somatostatin analogs have been reviewed extensively before $[12,67]$. While the inhibitory effects of somatostatin (analogs) on adenylyl cyclase activity and $\mathrm{Ca}^{2+}$ influxes are linked to inhibition of hormone secretion [30], the mechanism of action of the direct, SS-R-mediated antiproliferative effects of somatostatin analogs is less clear. Both cAMP-dependent and -independent and pertussis toxin-sensitive and -insensitive mechanisms have been proposed to be involved in direct, SS-R-mediated cell growth inhibitory effects in different cell systems [68-70]. Moreover, Liebow et al. [71] showed that the somatostatin analog RC160 , but not octreotide, inhibited proliferation of MiaPaCa-2 pancreatic tumor cells via stimulation of a tyrosine phosphatase, thereby promoting dephosphorylation of the epidermal growth factor (EGF) receptor. On the basis of the discrepancy between the effects of RC-160 and octreotide, it was concluded that the antihormonal and antiproliferative effects by somatostatin may be mediated via different SS-Rs [71]. Other studies, however, have shown that octreotide can also stimulate phosphatase activity [72]. We showed in $7315 \mathrm{~b}$ rat prolactin secreting pituitary tumor cells a dissociation between the antihormonal and antiproliferative effects induced by octreotide [70]. Freshly dispersed $7315 \mathrm{~b}$ tumor cells do not express receptors for octreotide, while the number of SS-R rapidly increased during culturing of the cells in medium containing $10 \%$ FBS. At a low SS-R number, only antihormonal effects were observed, whereas at a higher SS-R number both antihormonal and antiproliferative effects of octreotide were found. Although there was a significant positive correlation between the inhibitory effect of octrestide on cell proliferation and the number of SS-R on 7315b tumor cells, the involvement of different SSTR subtypes could not be excluded [70]. Recently, we found that SS-R expression in $7315 \mathrm{~b}$ tumor cells is highly estrogen dependent and that two major molecular forms of the SS-R ( 30 and $57 \mathrm{kDa}$ ), as determined by crosslinking of $\left[{ }^{125} \mathrm{I}-\mathrm{Tyr}^{3}\right]$ octreotide to its receptor, were all stimulated by $\mathrm{E}_{2}{ }^{*}$. The presence of different molecular forms of the SS-R may represent different processing variants of the same SSTR or different SSTR subtypes (see section on cross-linking studies). In addition to this stimulatory effect of $E_{2}$ on SS-R expression, which has also been observed in normal rat pituitary cells $[73,74]$, glucocorticoids have a potent down-regulating effect on SS-R expression in

\footnotetext{
* Visser-Wisselaar et al., Manuscript submitted for
} publication. 
pituitary tumor cells [75]; thyroid hormones also may affect the number of SS-Rs [76]. Whether these hormones exert similar effects on SS-R expression in non-pituitary tumor cells is unknown. Finally, SS$R$ expression may undergo either homologous downregulation after exposure to somatostatin as has been shown in AtT20 mouse pituitary tumor cells [77], or homologous up-regulation as has been shown in $\mathrm{GH}_{4} \mathrm{C}_{1}$ rat pituitary tumor cells [78], whereas in vivo treatment of experimental tumor models with somatostatin analogs may also result in an increased number of somatostatin binding sites [79]. It would be of interest to know whether this up-regulation and/or down-regulation of SS-R is related to a particular SSTR subtype(s).

Finally, when studying the effects of somatostatin and somatostatin analogs on cell proliferation, other interesting ubservations have been made. In different cell systems such as rat mesangial cells [80], human hepatoma cells [69] and human pancreatic carcinoid cells [81], both inhibitory and stimulatory effects by somatostatin (analogs) have been observed, depending on the culture conditions. In the absence of growth-stimulatory factors (i.e. FBS or insulin), stimulatory effects by somatostatin (analogs) are observed, whereas in FBS- or insulin-stimulated cultures predominantly inhibitory effects are seen. This strong dependency of the cell growth inhibitory effect by somatostatin (analogs) on the hormonal environment of the cells is also seen in human breast cancer cells [61]. In human meningioma tumor cell cultures, Koper et al. [82] also found a stimulatory effect of the somatostatin analog octreotide on cell proliferation. Somatostatin inhibited forskolinstimulated cAMP formation in membrane preparations of the meningiomas, and it was hypothesized that stimulation by somatostatin (analogs) of the proliferation of human meningioma cells in vitro may be mediated via interference in the autocrine negative control of tumor cell growth due to inhibition of intracellular cAMP levels. In different human follicular and papillary carcinoma cell lines, variable effects have been reported of the effects of the somatostatin analogs octreotide and MK-678 on cell proliferation [83]. Whereas MK-678 inhibited cell proliferation in one follicular carcinoma cell line, octreotide induced a stimulatory effect on the same cell line. In a papillary carcinoma cell line, MK-678 significantly inhibited cell growth in a concentration-dependent manner, while the same cells showed a biphasic response to octreotide with an inhibition of cell proliferation at 0.2 to $10 \mathrm{nM}$ and no significant effect on cell proliferation at higher concentrations. Finally, these investigators found that thyroid-stimulating hormone (TSH) and EGF altered the concentration-response relationship of MK-678 on the growth of another follicular carcinoma cell line. Taken together, it might be speculated that SSTR subtype expression is highly sensitive to regulatory effects of hormones, growth factors and/or steroid hormones, resulting in stimulatory effects as well as inhibitory effects by somatostatin (analogs) on the same cell type.

We recently compared the effects of octreotide, BIM-23014 and RC-160 on hormone release by cultured cells from human GH-secreting pituitary adenomas, from one gastrinoma, and from normal rat anterior pituitary cells [84]. We found that RC160 was significantly more potent in its inhibitory effect on hormone release as compared with octreotide and BIM-23014 in all three cell systems. It is still unclear at present whether the difference between the hormone release inhibitory effects of these analogs is caused by interactions via different SSTR subtypes. However, our data may be in accordance with several reports of a higher affinity of RC-160 as compared with octreotide for certain hSSTR subtypes.

At present, it is also unclear which hSSTR subtype mediates the antiproliferative (or proliferative) effects of somatostatin analogs such as octreotide, BIM-23014 and RC-160. Since the hSSTR2 subtype, to which these analogs bind with high affinity, seems to be coupled to buth inhibition of adenylyl cyclase activity and stimulation of phosphatase activity, this hSSTR subtype may be a candidate for mediating both effects. The hSSTR5 subtype, which is also coupled to adenylyl cyclase activity and which binds octreotide and RC-160 with a relative high affinity, may also be a candidate in cAMP-dependent inhibition of cell proliferation. However, the hSSTR5 subtype was not expressed in insulinomas, gastrinomas and carcinoids [57]. In the study by Greenman and Melmed [54], no correlation was found between SSTR subtype expression and tumor size of human pituitary adenomas. However, the four non-functioning adenomas and the GHsecreting tumor that did not express hSSTR1 or 2 (see above) were particularly large and invasive

Therefore, again the central question at this time remains: what is the functional role of the hSSTR subtypes, other than the hSSTR2 subtype, in this respect?

Somatostatin receptor-mediated internalization of somatostatin analogs: Relation to somatostatin receptor subtypes

Receptor-mediated endocytosis of SS14 or SS28 has been demonstrated in normal and tumorous rat pituitary cells and in rat islet cells [85-92]. On the other hand, Presky and Schonbrunn [93] and Sullivan and Schonbrunn [94] found that ${ }^{125}{ }^{12}$-Tyr $\left.{ }^{1}\right]$ SS14 and $\left.{ }^{[25} \mathrm{I}-\mathrm{Tyr}^{11}\right] \mathrm{SS} 14$ are not rapidly internalized, probably due to a rapid degradation of these radioligands by membrane proteases, in $\mathrm{GH}_{4} \mathrm{C}_{1}$ rat pituitary tumor cells and in RINm5F insulinoma cells, respectively. We recently found that the stable somatostatin analog $\mathrm{Tyr}^{3}$-octreotide was rapidly internalized in a high amount by AtT20 mouse pituitary tumor cells and in human GH-secreting pituitary adenoma cells*. In addition, we found that cultured cells from a human carcinoid also internalized this somatostatin analog to a high extent $\left(2 \%\right.$ of the dose of ${ }^{125} \mathrm{I}$ $\mathrm{Tyr}^{3}$ ]octreotide added, after $4 \mathrm{hr}$ of incubation; Table 2). Internalization of octreotide may well explain the rather long residence time of radioactivity on human tumors in vivo in SS-R scintigraphy $[12,95-97]$. A high rate of internalization is also of special importance when radiotherapy of certain SS$\mathrm{R}$-positive human cancers with $\alpha$ - or $\beta$-emitting

\footnotetext{
* Hofland et al., Manuscript submitted for publication.
} 
isotopes coupled to somatostatin analogs is considered $[12,20,98]$. It would be of interest to know which hSSTR subtype(s) shows internalization in order to develop somatostatin analogs with high affinity for this particular subtype(s) that can be used for radiotherapy, and to investigate whether it is possible to (transiently) up-regulate the expression of this SSTR subtype(s) in order to improve the results of in vivo SS-R scintigraphy as well as the effects of radiotherapy using radiolabeled somatostatin analogs.

As has been discussed above, at least five different human SSTR subtypes have been cloned. All subtypes bind SS14 and SS28 with high affinity, whereas their affinity for numerous somatostatin analogs differs considerably. Octreotide binds with high affinity to the SSTR2 subtype, while this analog has a relatively high affinity to SSTR3 and SSTR5 and shows no binding to SSTR subtypes 1 and 4 . At present, it is unclear which SSTR subtype is involved in receptor-mediated endocytosis. Coupling to $\mathrm{G}$ proteins seems to play a major role in agonistinduced receptor internalization [99]. Of interest in this respect is that the hSSTR2, hSSTR3 and hSSTR5 subtypes are linked to both pertussis toxin-sensitive and -insensitive GTP-binding proteins [49, 50].

\section{Future prospects}

In conclusion, the recent cloning of at least five different somatostatin receptor subtypes has provided a major tool to study hSSTR subtype expression in human tumors. Furthermore, studies concerning the coupling of second messenger systems to hSSTR subtypes, as well as investigations linking hSSTR subtype expression to their function (i.e. antihormonal and antiproliferative effects), will give new insights into the functional role of hSSTR subtypes in human tumors. Finally, the development of new classes of somatostatin analogs with specificity to particular hSSTR subtypes may provide us with new drugs for the treatment of patients with tumors carrying SSTRs with low affinity for octapeptide analogs such as octreotide, BIM-23014 and RC-160.

\section{REFERENCES}

1. Krulich I, Dhariwal APS and McCann SM, Stimulatory and inhibitory effects of purified hypothalamic extracts on growth hormone release from rat pituitary in vitro. Endocrinology 83: 783-790, 1968.

2. Brazeau $P$, Vale $W$, Burgus $R$, Ling $N$, Butcher $M$, Rivier $\mathbf{J}$ and Guillemin $\mathbf{R}$, Hypothalamic polypeptide that inhibits the secretion of immunoreactive pituitary growth hormone. Science 179: 77-79, 1973.

3. Pradayrol L, Jörnvall $H$, Mutt $V$ and Ribet, A, $\mathrm{N}$-terminally extended somatostatin: The primary structure of somatostatin-28. FEBS Lett 109: 55-58, 1980.

4. Benoit R, Esch F, Bennett HPJ, Ling N, Ravazzola M, Orci L and Mufson EJ, Processing of prosomatostatin. Metabolism 39: 22-25, 1990.

5. Guillemin R and Gerich JE, Somatostatin: Physiological and clinical significance. Annu Rev Med 27: 379-388, 1976.

6. Renaud L, Martin J and Brazeau P, Depressant action of TRH, LH-RH and somatostatin on activity of central neurones. Nature 255: 233-235, 1975.

7. Dodd $\mathbf{J}$ and Kelly $\mathbf{J}$, Is somatostatin an excitatory transmitter in the hippocampus? Nature 273: 674-675, 1978.

8. Guillemin R, Peptides in the brain: The new endocrinology of the neuron. Science 202: $390-402$, 1978.

9. Lamberts SWJ, The role of somatostatin in the regulation of anterior pituitary hormone secretion and the use of its analogs in the treatment of human pituitary tumors. Endocr Rev 9: 417-436, 1988.

10. Besser GM, Mortimer CH, McNeilly AS, Thorner MO, Batistoni GA, Bloom SR, Kastrup KW, Hanssen KF, Hall R, Coy DH, Kastin AJ and Schally AV, Long-term infusion of growth hormone release inhibiting hormone in acromegaly: Effects on pituitary and pancreatic hormones. Br Med J 4: 622-627, 1974.

11. Besser GM, Mortimer CH, Carr D, Schally AV, Coy DH, Evered D, Kastin AJ, 'Tunbridge WMG, 'Ihorner MO and Hall R, Growth hormone release inhibiting hormone in acromegaly. Br Med J 1: 352-355, 1974.

12. Lamberts SWJ, Krenning EP and Reubi JC, The role of somatostatin and its analogs in the diagnosis and treatment of tumors. Endocr Rev 12: 450-482, 1991.

13. Bauer W, Briner U, Doepfner W, Haller R, Huguenin R, Marbach P, Petcher TJ and Pless J, SMS 201-995: A very potent and selective octapeptide analogue of somalostatin with prolonged action. Life Sci 31: 1133$1140,1982$.

14. Cai R-Z, Szoke B, Lu R, Fu D, Redding TW and Schally AV, Synthesis and biological activity of highly potent octapeptide analogs of somatostatin. Proc Natl Acad Sci USA 83: 1896-1900, 1986.

15. Cai R-Z, Karashima T, Guoth J, Szokc B, Olsen D and Schally AV, Superactive octapeptide somatostatin analogues containing tryptophan at position 1. Proc Natl Acad Sci USA 84: 2502-2506, 1987.

16. Parmar H, Bogden A, Mollard M, de Rougé B, Phillips RH and Lightman SL, Somatostatin and somatostatin analogues in oncology. Cancer Treat Rev 16: 95-115, 1989.

17. Heiman ML, Murphy WA and Coy DH, Differential binding of somatostatin agonists to somatostatin receptors in brain and adenohypophysis. Neuroendocrinology 45: 429-436, 1987.

18. Reubi JC, Laissue J, Krenning E and Lamberts SWJ, Somatostatin receptors in human cancer: Incidence, characteristics, functional correlates and clinical implications. I Steroid Biochem Mol Biol 43: 27-35, 1992.

19. Reubi JC, Krenning E, Lamberts SWJ and Kvols L, In vitro detection of somatostatin receptors in human tumors. Metabolism 41: 104-110, 1992.

20. Krenning EP, Kwekkeboom DJ, Bakker WH, Breeman WAP, Kooij PPM, Oei HY, van Hagen M, Postema PTE, de Jong $M$, Reubi JC, Visser TJ, Reijs AEM, Hofland LJ, Koper JW and Lamberts SWJ, Somatostatin receptor scintigraphy with $\left[{ }^{111}\right.$ In-DTPAD-Phe ${ }^{1}$ - and [123I-Tyr $\left.{ }^{3}\right]$-octreotide: The Rotterdam experience with more than 1000 patients. Eur J Nucl Med 20: 716-731, 1993.

21. Reubi J-C, Evidence of two somatostatin-14 receptor types in rat brain cortex. Neurosci Lett 49: 259-263, 1984.

22. Reubi JC, New specific radioligand for one subpopulation of brain somatostatin receptors. Life $S c i$ 36: 1829-1836, 1985.

23. Tran V, Beal MF and Martin JB, Two types of somatostatin receptors differentiated by cyclic somatostatin analogs. Science 228: 492-495, 1985.

24. Maurer R and Reubi JC, Brain somatostatin receptor subpopulation visualized by autoradiography. Brain Res 333: 178-181, 1985.

25. Reubi J-C, Probst A, Cortes $R$ and Palacios JM, Distinct topographical localization of two somatostatin 
receptor subpopulations in the human cortex. Brain Res 406: 391-396, 1987.

26. Markstein R, Stöckli KA and Reubi JC, Differential effects of somatostatin on adenylate cyclase as functional correlate for different brain somatostatin receptor subpopulations. Neurosci Lett 104: 13-18, 1989.

27. Srkalovic G, Cai R-Z and Schally AV, Evaluation of receptors for somatostatin in various tumors using different analogs. J Clin Endocrinol Metab 70: 661$669,1990$.

28. Rens-Domiano $\mathrm{S}$ and Reisine $\mathrm{T}$, Biochemical and functional properties of somatostatin receptors. $J$ Neurochem 58: 1987-1996, 1992.

29. Murthy KK, Srikant CB and Patel YC, Evidence for multiple protein constituents of the somatostatin receptor in pituitary tumor cells: Affinity cross-linking and molecular characterization. Endocrinology 125: 948-956, 1989.

30. Patel YC, Murthy KK, Escher EE, Banville D, Spiess $J$ and Srikant $C B$, Mechanism of action of somatostatin: An overview of receptor function and studies of the molecular characterization and purification of somatostatin receptor proteins. Metabolism 39: 63-69, 1990.

31. Eppler CM, Zysk JR, Corbett $M$ and Shieh H-M, Purification of a pituitary receptor for somatostatin. $J$ Biol Chem 267: 15603-15612, 1992.

32. Rens-Dumiano $S$ and Reisine $T$, Structural analysis and functional role of the carbohydrate component of somatostatin receptors. J Biol Chem 266: 20094-20102, 1991.

33. Patel YC, Panetta R, Escher E, Greenwood M and Srikant $\mathrm{CB}$, Expression of multiple somatostatin receptor genes in AtT-20 cells. $J$ Biol Chem 269: 15061509,1994

34. Prévost G, Lanson M, Thomas F, Vever N, Gonzalez W, Beaupain R, Starzec A and Bogden A, Molecular heterogeneity of somatostatin analogue BIM-23014C receptors in human breast carcinoma cells using the chemical cross-linking assay. Cancer Res 52: 843-850, 1992.

35. Prévost G, Provost P, Sallé V, Lanson M and Thomas $F$, A cross-linking assay allows the detection of receptors for the somatostatin analogue, lanreotide in human breast tumours. Eur J Cancer 29: 1589-1592, 1993.

36. Yamada Y, Kagimoto S, Kubota A, Yasuda K, Masuda K, Someya $Y$, Ihara $Y, L i ~ Q$, Imura $H$, Seino $S$ and Seino $Y$, Cloning, functional expression and pharmacological characterization of a fourth (hSSTR4) and a fifth (hSSTR5) human somatostatin receptor subtype. Biochem Biophys Res Commun 195: 844-852, 1993.

37. Yamada $Y$, Stoffel M, Espinosa R III, Xiang K-S, Seino $M$, Seino S, Le Beau MM and Bell GI, Human somatostatin receptor genes: Localization to human chromosomes 14, 17, and 22 and identification of simple tandem repeat polymorphisms. Genomics 15 : 449-452, 1993.

38. Panetta R, Greenwood MT, Warszynska A, Demchyshyn LL, Day R, Niznik HB, Srikant CB and Patel $\mathrm{YC}$, Molecular cloning, functional characterization, and chromosomal localization of a human somatostatin receptor (somatostatin receptor type 5) with preferential affinity for somatostatin-28. Mol Pharmacol 45: 417427, 1994.

39. Demchyshyn LL, Srikant CB, Sunahara RK, Kent G, Seeman P, van Tol HHM, Panetta R, Patel YC and Niznik $\mathrm{HB}$, Cloning and expression of a human somatostatin-14-selective receptor variant (somatostatin receptor 4) located on chromosome 20 . Mol Pharmacol 43: 894-901, 1993.
40. Corness JD, Demchyshyn LL, Seeman P, van Tol HHM, Srikant CB, Kent G, Patel YC and Niznik HB, A human somatostatin receptor (SSTR3), located on chromosome 22, displays preferential affinity for somatostatin-14 like peptides. FEBS Lett 321: 279284, 1993.

41. Yasuda K, Espinosa R III, Davis EM, Le Beau MM and Bell GI, Human somatostatin receptor genes: Localization of SSTRS to human chromosome 20p11.2. Genomics 17: 785-786, 1993.

42. Bruno JF, Xu Y, Song J and Berelowitz M, Molecular cloning and functional expression of a brain-specific somatostatin receptor. Proc Natl Acad Sci USA 89: 11151-11155, 1992.

43. Yasuda K, Rens-Domiano S, Breder CD, Law SF, Saper CB, Reisine $T$ and Bell GI, Cloning and functional characterization of a novel somatostatin receptor, SSTR3, coupled to adenylyl cyclase. $J$ Biol Chem. 267: 20422-20428, 1992.

44. Yamada Y, Reisine T, Law SF, Ihara Y, Kubota A, Kagimoto S, Seino M, Seino Y, Bell GI and Seino S, Somatostatin receptors, an expanding gene family: Cloning and functional characterization of human SSTR3, a protein coupled to adenylyl cyclase. Mol Endocrinol 6: 2136-2142, 1992.

45. Rens-Domiano S, Law SF, Yamada Y, Seino S, Bell GI and Reisine T, Pharmacological properties of two cloned somatostatin receptors. Mol Pharmacol 42: 2834, 1992.

46. Raynor K, O'Carrol A-M, Kong H, Yasuda K, Mahan LC, Bell GI and Reisine T, Characterization of cloned somatostatin receptors SSTR4 and SSTR5. Mol Pharmacol 44: 385-392, 1993.

47. Kaupmann K, Bruns C, Hoyer D, Seuwen K and Lübberts $H$, Distribution and second messenger coupling of four somatostatin receptor subtypes expressed in brain. FEBS Lett 331: 53-59, 1993.

48. Patel YC, Greenwood MT, Warszynska A, Panetta R and Srikant CB, All five cloned human somatostatin receptors (hSSTR1-5) are functionally coupled to adenylyl cyclase. Biochem Biophys Res Commun 198: 605-612, 1994.

49. Tomura H, Okajima F, Akbar M, Majid MA, Sho K and Kondo $\mathrm{Y}$, Transfected human somatostatin receptor type 2, SSTR2, not only inhibits adenylate cyclase but also stimulates phospholipase $\mathrm{C}$ and $\mathrm{Ca}^{2+}$ mobilization. Biochem Biophys Res Commun 200: 986992, 1994.

50. Akbar M, Okajima F, Tomura H, Majid MA, Yamada $\mathrm{Y}$, Seino $\mathrm{S}$ and Kondo $\mathrm{Y}$, Phospholipase $\mathrm{C}$ activation and $\mathrm{Ca}^{2+}$ mobilization by cloned human somatostatin receptor subtypes $1-5$, in transfected COS-7 cells. FEBS Lett 348: 192-196, 1994.

51. Buscail L, Delescque N, Estève J-P, Saint-Laurent N, Prats H, Clerc P, Robberecht P, Bell GI, Liebow C, Schally AV, Vaysse $N$ and Susini $C$, Stimulation of tyrosine phosphatase and inhibition of cell proliferation by somatostatin analogues: Mediation by human somatostatin receptor subtypes SSTR1 and SSTR2. Proc Natl Acad Sci USA 91: 2315-2319, 1994.

52. Raynor K, Murphy WA, Coy DH, Taylor JE, Moreau J-P, Yasuda K, Bell GI and Reisine T, Cloned somatostatin receptors: Identification of subtypeselective peptides and demonstration of high affinity binding of linear peptides. Mol Pharmacol 43: 838844, 1993.

53. Rohrer L, Raulf F, Bruns C, Buettner R, Hofstaedter $\mathrm{F}$ and Schüle $\mathrm{R}$, Cloning and characterization of a fourth human somatostatin receptor. Proc Natl Acad Sci USA 90: 4196-4200, 1993.

54. Greenman $Y$ and Melmed $S$, Heterogeneous expression of two somatostatin receptor subtypes in pituitary tumors. J Clin Endocrinol Metab 78: 398-403, 1994. 
55. de Bruin TWA, Kwekkeboom DJ, Van't Verlaat JW, Reubi J-C, Krenning EP, Lamberts SWJ and Croughs RJM, Clinically nonfunctioning pituitary adenoma and octreotide response to long term high dose treatment, and studies in vitro. J Clin Endocrinol Metab 75: 1310$1317,1992$.

56. Katznelson L, Oppenheim DS, Coughlin JF, Kliman B, Schoenfeld DA and Klibansky A, Chronic somatostatin analog administration in patients with $\alpha$ subunit-secreting pituitary tumors. J Clin Endocrinol Metab 75: 1318-1325, 1992.

57. Kubota A, Yamada Y, Kagimoto S, Shimatsu A, Imamura M, Tsuda K, Imura H, Seino S and Seino Y, Identification of somatostatin receptor subtypes and an implication for the efficacy of somatostatin analogue SMS 201-995 in treatment of human endocrine tumors. $J$ Clin Invest 93: 1321-1325, 1994.

58. Reubi JC, Horisberger U and Laissue J, High density of somatostatin receptors in veins surrounding human cancer tissue: Role in tumor-host interaction? Int $J$ Cancer 56: 681-688, 1994.

59. Reubi JC, Schaer JC, Waser B and Mengod G, Expression and localization of somatostatin receptor SSTR1, SSTR2, and SSTR3 messenger RNAs in primary human tumors using in situ hybridization. Cancer Res 54: 3455-3459, 1994.

60. Eden PA and Taylor JE, Somatostatin receptor subtype gene expression in human and rodent tumors. Life Sci 53: 85-90, 1993.

61. Setyono-Han B, Henkelman MS, Foekens JA and Klijn JGM, Direct inhibitory effects of somatostatin (analogues) on the growth of human breast cancer cells. Cancer Res 47: 1566-1570, 1987.

62. Pagliacci $M C$, Tognellini $R$, Grignani $F$ and Nicoletti I, Inhibition of human breast cancer cell (MCF-7) growth in vitro by the somatostatin analog SMS 201995; Effects on cell cycle parameters and apoptotic cell death. Endocrinology 129: 2555-2562, 1991.

63. Prévost, G, Foehrlé E, Thomas F, Pihan I, Veber N, Starzec $A$ and Israël L, Growth of human breast cancer cell lines is inhibited by the somatostatin analog BIM23014. Endocrinology 129: 323-329, 1991.

64. Weckbecker G, Liu RL, Tolcsvai L and Bruns C, Antiproliferative effects of the somatostatin analogue octreotide (SMS 201-995) on ZR-75-1 human breast cancer cells in vivo and in vitro. Cancer Res 52: 49734978, 1992

65. Scambia G, Panici PB, Baiocchi G, Perrone L, Iacobelli $\mathrm{S}$ and Mancuso S, Antiproliferative effects of somatostatin and the somatostatin analog SMS 201995 on three human breast cancer cell lines. $J$ Cancer Res Clin Oncol 114: 306-308, 1988.

66. Nelson J, Cremin M and Murphy RF, Synthesis of somatostatin by breast cancer cells and their inhibition by exogenous somatostatin and sandostatin. $\mathrm{Br} J$ Cancer 59: 739-742, 1989.

67. Schally AV, Oncological applications of somatostatin analogues. Cancer Res 48: 6977-6985, 1988.

68. Viguerie N, Tahiri-Jouti N, Ayral AM, Cambillau C, Scemama JL, Bastie MJ, Knuhtsen S, Esteve JP, Pradayrol L, Susini C and Vaysse N, Direct inhibitory effects of a somatostatin analog, SMS 201-995, on AR4-2J cell proliferation via pertussis toxin-sensitive guanosine triphosphate-binding protein-independent mechanism. Endocrinology 124: 1017-1025, 1989.

69. Chou CK, Ho LT, Ting LP, Hu CP, Su TS, Chang WC, Suen CS, Huang MY and Chang C, Selective suppression of insulin-induced proliferation of cultured human hepatoma cells by somatostatin. $J$ Clin Invest 79: $175-178,1987$.

70. Hofland LJ, van Koetsveld PM, Wouters N, Waaijers $M$, Reubi J-C and Lamberts SWJ, Dissociation of antiproliferative and antihormonal effects of the somatostatin analogue octreotide on $7315 \mathrm{~b}$ pituitary tumor cells. Endocrinology 131: 571-577, 1992.

71. Liebow C, Reilly C, Serrano $M$ and Schally AV, Somatostatin analogues inhibit growth of pancreatic cancer by stimulating tyrosine phosphatase. Proc Natl Acad Sci USA 86: 2003-2007, 1989.

72. Colas B, Cambillau C, Buscail L, Zeggari M, Esteve J-P, Lautre V, Thomas F, Vaysse $\mathrm{N}$ and Susini $\mathrm{C}$, Stimulation of a membrane tyrosine phosphatase activity by somatostatin analogues in rat pancreatic acinar cells. Eur J Biochem 207: 1017-1024, 1992

73. Kimura N, Hayafuji $C$ and Kimura $N$, Characterization of 17- $\beta$-estradiol-dependent and -independent somatostatin receptor subtypes in rat anterior pituitary. $J$ Biol Chem 264: 7033-7040, 1989.

74. Kimura N, Hayafuji C, Konagaya $H$ and Takahashi $K$, $17 \beta$-Estradiol induces somatostatin (SRIF) inhibition of prolactin release and regulates SRIF receptors in rat anterior pituitary cells. Endocrinology 119: 1028$1036,1986$.

75. Schonbrunn A, Glucocorticoids down-regulate somatostatin receptors on pituitary cells in culture. Endocrinology 110: 1147-1154, 1982.

76. Hinkle PM, Perrone MH and Schonbrunn A Mechanism of thyroid hormone inhibition of thyrotropin-releasing hormone action. Endocrinology 108 : 199-205, 1981.

77. Srikant $B$ and Heisler S, Relationship between receptor binding and biopotency of somatostatin-14 and somatostatin-28 in mouse pituitary tumor cells. Endocrinology 117: 271-278, 1985.

78. Presky DH and Schonbrunn A, Somatostatin pretreatment increases the number of somatostatin receptors on $\mathrm{GH}_{4} \mathrm{C}_{1}$ pituitary cells and does not reduce cellular responsiveness to somatostatin. J Biol Chem 263: 714-721, 1988.

79. Pinsky J, Halmos G, Yano T, Szeperhazi K, Qin Y, Ertl T and Schally AV, Inhibition of growth of MKN45 human gastric-carcinoma xenografts in nude mice by treatment with bombesin/gastrin-releasing-peptide antagonist (RC-3095) and somatostatin analogue RC. 160. Int J Cancer 57: 574-580, 1994.

80. Ruiz-Torres P, Lucio FJ, González-Rubio $M$, Rodríguez-Puyol $M$ and Rodríguez-Puyol D, A dual effect of somatostatin on the proliferation of cultured rat mesangial cells. Biochem Biophys Res Commun 195: 1057-1062, 1993.

81. Ishizuka J, Beauchamp RD, Evers BM, Townsend CM $\mathrm{J}_{\mathrm{r}}$ and Thompson JC, Unexpected growth-stimulatory effect of somatostatin analogue on cultured human pancreatic carcinoid celts. Biochem Biophys Res Commun 185: 577-581, 1992.

82. Koper JW, Markstein R, Kohler C, Kwekkeboom DJ, Avezaat CJJ, Lamberts SWJ and Reubi J-C, Somatostatin inhibits the activity of adenylate cyclase in cultured human meningioma cells and stimulates their growth. J Clin Endocrinol Metab 74: 543-547, 1992.

83. Ain KB and Taylor KD, Somatostatin analogs affect proliferation of human thyroid carcinoma cell lines in vitro. J Clin Endocrinol Metab 78: 1097-1102, 1994.

84. Hofland LJ, van Koetsveld PM, Waaijers M, Zuyderwijk J and Lamberts SWJ, Relative potencies of the somatostatin analogs octreotide, BIM-23014, and $\mathrm{RC}-160$ on the inhibition of hormone release by cultured human endocrine tumor cells and normal rat anterior pituitary cells. Endocrinology 134: 301-306, 1994.

85. Morel G, Mesguich P, Dubois MP and Dubois PM, Ultrastructural evidence for endogenous somatostatinlike immunoreactivity in the pituitary gland. Neuroendocrinology 36: 291-299, 1983.

86. Morel G, Pelletier G and Heisler S, Internalization and 
subcellular distribution of radiolabeled somatostatin-28 in mouse anterior pituitary tumor cells. Endocrinology 119: 1972-1979, 1986.

87. Morel G, Leroux $P$ and Pelletier G, Ultrastructura autoradiographic localization of somatostatin-28 in the rat anterior pituitary gland. Endocrinology 116: 16151619,1985

88. Amherdt M, Patel YC and Orci L, Binding and internalization of somatostatin, insulin, and glucagon by cultured rat islet cells. J Clin Invest 84: 412-417, 1989.

89. Draznin B, Sherman N, Sussman K, Dahl R and Vatter $A$, Internalization and cellular processing of somatostatin in primary cultures of rat anterior pituitary cells. Endocrinology 117: 960-966, 1985.

90. Mentlein R, Buchholz C and Krisch B, Binding and internalization of gold-conjugated somatostatin and growth hormone-releasing hormone in cultured rat somatotropes. Cell Tissue Res 258: 309-317, 1989.

91. Steiner C, Dahl R, Sherman N, Trowbridge M, Vatter A, Robbins R and Draznin B, Somatostatin receptors are biologically active before they are inserted into the plasma membrane. Endocrinolugy 118: 766-772, 1986.

92. Sussman KE, Mehler PS, Leitner JW and Draznin B, Role of the secretion vesicle in the transport of receptors: Modulation of somatostatin binding to pancreatic islets. Endocrinology 111: 316-323, 1982.

93. Presky DH and Schonbrunn A, Receptor-bound somatostatin and epidermal growth factor are processed differently in $\mathrm{GH}_{4} \mathrm{C}_{1}$ rat pituitary cells. $J$ Cell Biol 102: 878-888, 1986.
94. Sullivan SJ and Schonbrunn A, The processing of receptor-bound $\left[{ }^{125} \mathrm{I}-\mathrm{Tyr}^{11}\right]$ somatostatin by $\mathrm{RINm} 5 \mathrm{~F}$ insulinoma cells. J Biol Chem 261: 3571-3577, 1986.

95. Krenning EP, Bakker WH, Breeman WAP, Koper JW, Kooij PPM, Ausema L, Lameris JS and Lamberts SWJ, Localization of endocrine-related tumours with radioiodinated analogue of somatostatin. Lancet 1: 242-244, 1989.

96. Bakker WH, Krenning EP, Breeman WAP, Kooij PPM, Reubi J-C, Koper JW, de Jong M, Lameris JS, Visser TJ and Lamberts SWJ, In vivo use of a radioiodinated somatostatin analogue: Dynamics, metabolism and binding to somatostatin receptor positive tumors in man. $J$ Nucl Med 32: 1184-1189, 1991.

97. Krenning EP, Bakker WH, Kooij PPM, Breeman WAP, Oei HY, de Jong M, Reubi JC, Visser 'TJ, Bruns C, Kwekkeboom DJ, Reijs AEM, van Hagen PM, Koper JW and Lamberts SWJ, Somatostatin receptor scintigraphy with indium-111-DTPA-D-Phe1-octreotide in man: Metabolism, dosimetry and comparison with iodine-123-Tyr-3-octreotide. J Nucl Med 33: 652-658, 1992.

98. Krenning EP, Kooy PPM, Bakker WHB, Breeman WAP, Postema PTE, Kwekkeboom DJ, Oei HY, de Jong M, Visser TJ, Reijs AEM and Lamberts SWJ, Radiotherapy with a radiolabeled somatostatin analog [ ${ }^{111}$ In-DTPA-D-Phe ${ }^{1}$ ]-octreotide: A case history. Ann NY Acad Sci 733: 496-506, 1994.

99. Laduron PM, From receptor internalization to nuclear translocation. Biochem Pharmacol 47: 3-13, 1994. 